\title{
The Level of Zinc is Increasing, while the Serum Folat Level is Decreasing, after Multi-Micronutrient Supplementation in Pregnant Woman
}

\author{
Kartini, Noroyono Wibowo \\ Maternal-Fetal Division \\ Department of Obstetrics and Gynecology/ \\ Dr. Cipto Mangunkusumo Hospital \\ Jakarta
}

Kadar Zinc Meningkat, sementara Kadar Asam Folat Menurun, setelah Pemberian Suplementasi Multivitamin dan Multimineral pada Perempuan Hamil

\begin{abstract}
Objective: To measure the changes of serum iron, folic acid, zinc and selenium level on pregnant woman after multi-micronutrient supplementation.

Method: First trimester pregnant woman whom attended MaternalFetal Policlinic at Dr. Cipto Mangunkusumo Hospital from July 2011 till October 2011 was considered into the study. The intervention was consumption of multi-micronutrient tablet once a day for three months period. The outcomes were the measurements of serum level of iron, folic acid, zinc and selenium before and after supplementation. We used paired T Test and Wilcoxon test for statistical analysis.
\end{abstract}

Results: Twenty-eight pregnant women in their first trimester participated in the study. The micronutrient serum level was measured before and after supplementation during the time period. Before supplementation, serum iron and zinc level were below normal. Serum selenium level was normal with higher than normal serum folic acid level. After supplementation, serum zinc level was found to be below normal. Both level of serum iron and selenium increased to normal. Serum folic level was higher than normal. We found a decrease in serum zinc level with an increase in serum folic acid level that was statistically significant (p 0.009; p 0.003 respectively). We also found a slight decrease of serum iron level and an increase of serum selenium level that were not statistically significant ( $p 0.295$; p 0.333).

Conclusion: There is a decreased level of serum zinc with an increase in serum folic acid level after multi-micronutrient supplementation.

[Indones J Obstet Gynecol 2012; 36-4: 171-5]

Keywords: multi-micronutrient, supplementation

\section{Abstrak}

Tujuan: Menilai adanya perubahan kadar mikronutrien besi, folat, zinc dan selenium pada perempuan hamil setelah pemberian multivitamin dan multimineral.

Metode: Perempuan hamil trimester 1 yang melakukan kunjungan antenatal di Poliklinik Fetomaternal Rumah Sakit Dr. Cipto Mangunkusumo periode Juli hingga Oktober 2011 masuk sebagai subjek penelitian. Intervensi dilakukan dengan memberikan multivitamin dan mineral yang dikonsumsi 1 tablet perhari selama 3 bulan. Pengukuran kadar besi, folat, zinc dan selenium serum sebelum dan sesudah pemberian multivitamin dan multimineral menjadi keluaran penelitian. Analisis statistik menggunakan uji T berpasangan dan uji Wilcoxon.

Hasil: Sebanyak 28 perempuan hamil trimester 1 yang bersedia ikut dalam penelitian dan menjalani pemeriksaan kadar mikronutrien sebelum dan sesudah pemberian multivitamin dalam periode penelitian. Sebelum pemberian multivitamin, kadar besi dan zinc di bawah normal, kadar selenium dalam batas normal dan kadar folat di atas normal. Pascasuplementasi multivitamin dan multimineral kadar zinc di bawah normal, kadar besi dan selenium dalam batas normal dan kadar folat di atas normal. Didapat penurunan kadar zinc dan peningkatan kadar folat pascasuplementasi yang bermakna secara statistik (p 0,009; $p 0,003)$. Didapat penurunan kadar besi dan peningkatan kadar selenium yang tidak bermakna secara statistik ( $p$ 0,295; $p$ 0,333).

Kesimpulan: Terdapat penurunan kadar zinc dan peningkatan kadar folat pascasuplementasi multivitamin dan multimineral.

[Maj Obstet Ginekol Indones 2012; 36-4: 171-5]

Kata kunci: mikronutrien, suplementasi multivitamin dan multimineral

Correspondence: Kartini, Department of Obstetrics and Gynecology. Dr. Cipto Mangunkusumo Hospital, Jakarta.

Telephone: 021-31908617, 0811-9848200. Email: umirifda@yahoo.com

\section{INTRODUCTION}

Micronutrients deficiencies are a major global health problem. More than 2 billion people in the world today are estimated to be deficient in vitamins and minerals, particularly vitamin $\mathrm{A}$, iodine, iron and zinc. ${ }^{1}$ One of the most vulnerable group of micronutrient deficiencies is pregnant women because they have greater need for vitamins and minerals and the impact may contribute to birth outcomes. $^{2}$

Studies have shown that micronutrient deficiencies contributed to maternal and neonatal morbid- 
ity and mortality. Iron deficiency anemia on pregnant women may increase the risk of death from post partum hemorrhage. Folic acid deficiency can lead to hematological consequences, pregnancy complications and congenital malformations. Zinc deficiency has been associated with preeclampsia, premature rupture of membranes, growth retardation and retarded neurobehavioral, also immunologic impairment of the fetus. ${ }^{3}$ Recurrent early pregnancy loss has been associated with reduced serum selenium concentration. ${ }^{4}$

Multiple micronutrient deficiencies often coexist and there is an increased interest in evaluating the benefit of multi-micronutrient supplementations in pregnancy. ${ }^{5}$ Trials on multi-micronutrient supplementation compared with iron-folic acid and the effect to maternal and neonatal outcomes have been done in many countries such as Indonesia, ${ }^{6}$ India, ${ }^{7}$ Zimbabwe, ${ }^{8}$ Nepal, ${ }^{9}$ Tanzania, ${ }^{10}$ Guinea Bissau, ${ }^{11}$ China, ${ }^{12}$ France, ${ }^{13}$ and USA, ${ }^{14}$ and have shown improvements in birth weight, reduction in intrauterine growth retardation, prematurity and infant morbidity.

Meta-analysis of the effects of prenatal multimicronutrient supplementation on pregnancy outcomes reported by Shah and Ohlsson, 2009, concluded that prenatal multi-micronutrient supplementation was associated with a significantly reduced risk of low birth weight and with improved birth weight when compared with iron-folic acid supplementation. But there is no significant effect of multi-micronutrient supplementations on the risk of preterm birth or small for gestational age infants. ${ }^{15}$

Most of health care providers worldwide nowadays give multi-micronutrient supplementations since first trimester of pregnancy, but there is insufficient evidence to prove the benefit from replacing iron-folic acid supplementation with multimicronutrient supplement during pregnancy. ${ }^{16}$

The effectiveness of multi-micronutrient supplementation have been questioned due to possible interaction among micronutrients resulting in their impaired absorption. ${ }^{5}$ This study aimed to evaluate the benefit of multi-micronutrient supplementation by measuring the changes in micronutrients serum level before and after supplementation and to show whether multi-micronutrient supplementation can meet the increasing need of micronutrients during pregnancy and achieved normal serum level on each trimester.

\section{METHODS}

We conducted a quasi-experimental study. This study was conducted from July 2011 to October 2011. First trimester pregnant women whom agreed to join this study and had the measurement of micronutrients serum level before and after the intervention was included in the study. The intervention was consuming multi-micronutrient tablet once a day for three- month period. The composition of multi-micronutrient are Omega-3 fatty acid (50\% DHA $150 \mathrm{mg}$ ) $300 \mathrm{mg}$, biotin $30 \mu \mathrm{g}$, chromium $30 \mathrm{mg}$, copper $1 \mathrm{mg}$, folic acid $600 \mathrm{mg}$, iodine $150 \mathrm{mg}$, Fe 14 mg, Mg 10 mg, molybdenum $50 \mu \mathrm{g}$, nicotinamide $18 \mathrm{mg}$, selenium $60 \mu \mathrm{g}, \beta$-carotene $1000 \mu \mathrm{g} / 2 \mathrm{mg}$, vit $\mathrm{B}_{1} 1.4 \mathrm{mg}$, vit $\mathrm{B}_{2} 1.9 \mathrm{mg}$, vit $\mathrm{B}_{12}$ $2.6 \mu \mathrm{g}$, vit C $85 \mathrm{mg}$, vit $\mathrm{D}_{1} 5 \mu \mathrm{g}$, vit E $15 \mathrm{mg}$, Zn 11 $\mathrm{mg}$.

Before the intervention, the women underwent blood examination and they must come back three months after the first procedure and after consuming 90 tablet of multi-micronutrient to undergo the second blood examination. Serum iron, zinc and selenium level were measured using ICP-OES (Inductively Coupled Plasma-Optical Emission Spectrometry) and serum folic acid level was determined using electrochemiluminescence immunoassay (ECLIA) method.

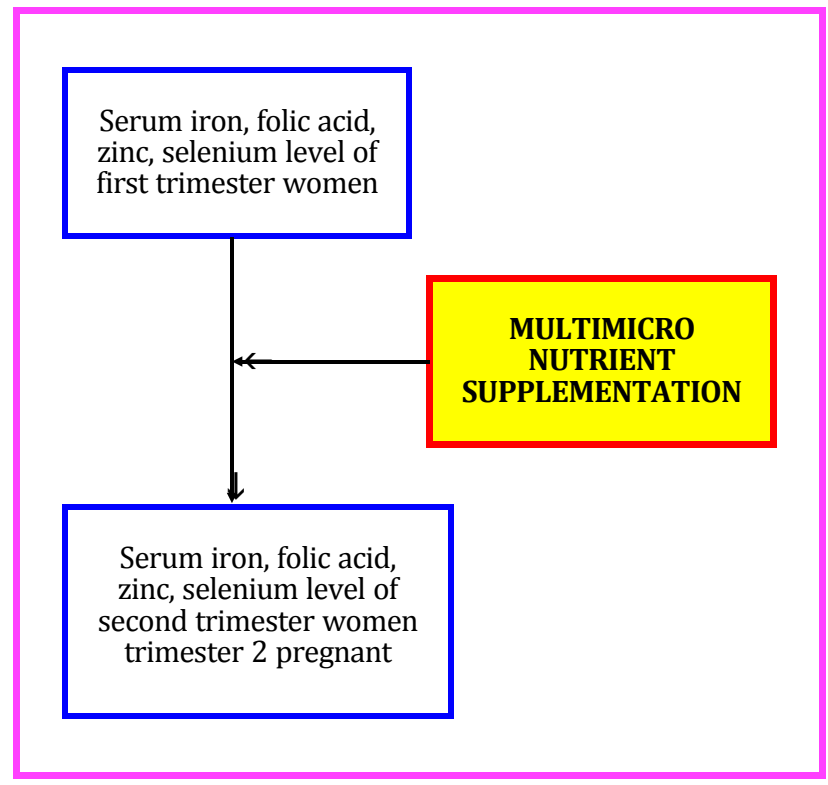

Figure 1. Schematic representation of study scheme Data analysis was conducted with Statistical Package for Social Science (SPSS Inc,) Version 17.0. Data about mean and standard deviation were measured. We used Kolmogorov Smirnov test for testing the normality of the data distribution. Statistical analysis was done with Paired T test and for data not normally distributed, Wilcoxon test was used. 


\section{RESULT}

We had a total of 28 pregnant women on first trimester, which agreed to join the research and had data before and after intervention on the research time period. From the age distribution data, the mean age was 29.74 years old (SD 3.32). Before supplementation, first trimester pregnant women in this research had low serum iron, zinc and selenium level, and high serum folic acid level.

\section{DISCUSSION}

This was a preliminary study of micronutrient on pregnancy study conducted in Fetomaternal Division, Department of Obstetrics and Gynecology, Dr. Cipto Mangunkusumo Hospital. For our knowledge, this was the first study to evaluate multi-micronutrient supplementation impact to micronutrient serum level of pregnant women conducted in Indonesia.

Table 1. Serum micronutrient level on first trimester women before supplementation

\begin{tabular}{|c|c|c|c|c|c|c|}
\hline Variable & Mean & Median & SD & Min & Max & $\begin{array}{l}\text { Normal value of } \\
1^{\text {st }} \text { trimester }\end{array}$ \\
\hline Folic acid* (ng/ml) & 21.48 & 20.30 & 7.14 & 11.10 & 40.70 & $2.6-15$ \\
\hline Iron* $(\mu \mathrm{g} / \mathrm{ml})$ & 6.25 & 5.91 & 3.01 & 1.54 & 18.30 & $7.2-14.3$ \\
\hline Selenium* $(\mu \mathrm{g} / \mathrm{ml})$ & 0.16 & 0.003 & 0.25 & 0.003 & 0.634 & $1.16-1.46$ \\
\hline $\operatorname{Zinc}^{*}(\mu \mathrm{g} / \mathrm{ml})$ & 1.03 & 1.23 & 0.59 & 0.02 & 2.05 & $5.7-8.8$ \\
\hline
\end{tabular}

*not normally distributed

After three months-multi-micronutrient supplementation, serum zinc and selenium level were below normal, serum iron was normal and serum folic acid was higher than normal.

Table 2. Serum micronutrient level on second trimester after multi-micronutrient supplementation

\begin{tabular}{|c|c|c|c|c|c|c|}
\hline Variable & Mean & Median & SD & Min & Max & $\begin{array}{l}\text { Normal value of } \\
2^{\text {nd }} \text { trimester }\end{array}$ \\
\hline Folic acid (ng/ml) & 26.28 & 26.75 & 4.84 & 16.40 & 35.00 & $0.8-24$ \\
\hline Iron $(\mu \mathrm{g} / \mathrm{ml})$ & 5.54 & 5.42 & 1.62 & 3.14 & 10.29 & $4.4-17.8$ \\
\hline Selenium* $(\mu \mathrm{g} / \mathrm{ml})$ & 0.18 & 0.003 & 0.27 & 0.003 & 0.686 & $0.75-1.45$ \\
\hline Zinc* $^{*}(\mu \mathrm{g} / \mathrm{ml})$ & 0.58 & 0.46 & 0.58 & 0.02 & 1.60 & $5.1-8.0$ \\
\hline
\end{tabular}

*Not normally distributed

Then we measured changes in the level of micronutrients and we found that folic acid and selenium level were increased and iron and zinc level was decreased after supplementation.

Using paired T test and Wilcoxon test, the increased level of serum folic acid and the decreased level of serum zinc were both statistically significant.

Table 3. Changes in Level of Micronutrient Serum after Multi-Micronutrient Supplementation

\begin{tabular}{lcccc}
\multicolumn{1}{c}{ Variable } & Mean & SD & $\mathbf{9 5 \% ~ C I ~}$ & $\mathbf{p}$ \\
\hline Folic acid* $(\mathrm{ng} / \mathrm{ml})$ & 4.80 & 4.10 & $(1.872)-(7.728)$ & 0.003 \\
Iron* $(\mu \mathrm{g} / \mathrm{ml})$ & -0.71 & -0.33 & $(-0.466)-(1.877)$ & 0.295 \\
Selenium** $(\mu \mathrm{g} / \mathrm{ml})$ & 0.028 & 0.173 & $(-0.039)-(0.095)$ & 0.333 \\
Zinc** $(\mu \mathrm{g} / \mathrm{ml})$ & -0.451 & 0.908 & $(-0.803)-(0.992)$ & 0.009 \\
\hline \hline
\end{tabular}

*Analysis using Paired T-Test with significancy $p<0.05$

${ }^{* *}$ Analysis using Wilcoxon test with significancy $p<0.05$ 
In our study, $100 \%$ of pregnant women had zinc serum level below normal on first and second trimester. After three months supplementation with $11 \mathrm{mg}$ zinc per day, serum zinc level was decreased by $43.69 \%$. This finding concluded that zinc dosage in multi-micronutrient supplementation was not adequate to meet the needs of second trimester pregnancy. Low zinc status, and interactions between other micronutrients and some substrates on daily food may impact zinc absorption or metabolism and further influence small zinc level in our study. ${ }^{17}$

Our results did not different with findings from many researchers about maternal zinc serum level. It is estimated about $82 \%$ of pregnant women worldwide suffered from zinc deficiency. ${ }^{18}$ In Indonesia, we have two previous studies about maternal zinc serum that was done in West Java and East Timor, and had reported that $70-90 \%$ pregnant women suffered from zinc deficiency. ${ }^{19}$

In contrast with zinc level, we found that the mean folic acid serum level on first and second trimester were higher than normal. Folic acid serum level increased by $22.35 \%$ after $600 \mu \mathrm{g} /$ day supplementation. It may be explained by the fact that adequate folic acid dose meet pregnant woman's need during pregnancy and the already normal to high folic acid status of all subjects in this study. Global prevalence of folic acid deficiency is uncertain due to a lack of data, ${ }^{17}$ and in Indonesia we also have no data about the prevalence of folic acid deficiency among pregnant women. Low plasma values are also rare in Guatemala, Mexico, and Thailand where diets typically contain a higher proportion of fruits and vegetables, but in United States before fortification of flour with folic acid about $15 \%$ adult women had low serum folic acid. Folic acid deficiency tend to be more prevalent in populations with high intake of refined cereal (which are low in folic acid) and a low intake of leafy greens and fruits (which are high in folic acid). ${ }^{17}$

We found mean serum iron to be below normal on first trimester and decreased by $11.36 \%$ on second trimester after $14 \mathrm{mg} \mathrm{Fe} /$ day supplementation. This finding was similar with the problem of iron deficiency anemia that was still high prevalence in Indonesia, from Household Health Survey (2001) anemia affected $40.1 \%$ pregnant women in Indonesia. ${ }^{20}$ Low dosage of iron from multi-micronutrient tablet may partially explain the decreased serum iron level in this study which cannot meet the increased need of iron on second trimester of pregnancy. Low iron status and interaction with other micronutrients especially zinc also contributed to the low serum iron in this study. ${ }^{17}$

Similar with iron serum, all pregnant women in our study had very low selenium serum level at first and second trimester. Although we found the increase of selenium serum level about $18.75 \%$ after $60 \mu \mathrm{g} /$ day supplementation but it was not adequate to meet selenium need during pregnancy.

This study did not evaluate the impact of micronutrient serum level on maternal and neonatal outcome, but some research about the impact had been done in Indonesia. A large study conducted in Lombok (SUMMIT Study Group, 2008) reported the effect of maternal multi-micronutrient supplementation to neonatal outcome on 31,920 pregnant woman in Lombok, Indonesia with a doubleblind cluster-randomized control design, and concluded that maternal multiple micronutrient supplementation compared with IFA (Iron-Folic acid) can reduce early infant mortality especially to undernourished and anemic woman. ${ }^{6}$

Although this study didn't use randomized clinical trial design, our findings suggest health care providers to carefully evaluate the content of multimicronutrient supplement before prescribing to pregnant woman and give them appropriate dose to meet their need. It would be best if we knew the status of micronutrient before supplementation to predict the appropriate multi-micronutrient composition and dosage for the pregnant woman.

\section{CONCLUSION}

There was a decreased serum zinc level and an increase in serum folic acid level after multi-micronutrient supplementation. Further research is needed to measure the optimal dosage of multi-micronutrient to achieve the normal serum level during pregnancy.

\section{REFERENCES}

1. Muller 0, Krawinkel M. Malnutrition and health in developing countries (Review). CMAJ. 2005; 173(3):279-86.

2. Berdanier CD, Zempleni J. Advanced nutrition: macronutrients, micronutrients, and metabolism. 2009.

3. Haider BA, Bhutta ZA. Mutiple-micronutrient supplementation for women during pregnancy (Review). The Cochrane collaboration. 2007; (4):1-29. 
4. Yetley EA. Multivitamin and multimineral dietary supplements: definitions, characterization, bioavailability, and drug interactions. Am J Clin Nutr. 2007; 85(suppl):269S-76S

5. Desay P, Patel P, Rathod SP, Mahajan S. Selenium level and glutathione perixidase activity in spontaneous inevitable abortion. J Obstet Gynecol India. 2006; 56(4): 311-4.

6. Shankar AH, Jahari AB, Sebayang SK, et al. Supplementation with Multiple Micronutrients Intervention Trial (SUMMIT) Study Group. Effect of maternal multiple micronutrient supplementation on fetal loss and infant death in Indonesia: a double-blind cluster-randomised trial. Lancet 2008; 371: 215-27.

7. Gupta P, Ray M, Dua T, Radhakrishnan G, Kumar R, Sachdev HP. Multi-micronutrient supplementation for undernourished pregnant women and the birth size of their off spring: a double-blind, randomized, placebo-controlled trial. Arch Pediatr Adolesc Med 2007; 161: 58-64.

8. Friis H, Gomo E, Nyazema N, et al. Effect of multi-micronutrient supplementation on gestational length and birth size: a randomized, placebo-controlled, double-blind effectiveness trial in Zimbabwe. Am J Clin Nutr 2004; 80: 178-84.

9. Osrin D, Vaidya A, Shrestha Y, et al. Effects of antenatal multiple micronutrient supplementation on birthweight and gestational duration in Nepal: double-blind, randomised controlled trial. Lancet 2005; 365: 955-62.

10. Fawzi WW, Msamanga GI, Urassa W, et al. Vitamins and perinatal outcomes among HIV-negative women in Tanzania. N Engl J Med 2007; 356: 1423-31.

11. Kaestel P, Michaelsen KF, Aaby P, Friis H. Effects of prenatal multi-micronutrient supplements on birth weight and perinatal mortality: a randomised, controlled trial in GuineaBissau. Eur J Clin Nutr 2005; 59: 108-89.
12. Zeng L, et al. Impact of micronutrient supplementation during pregnancy on birthweight, duration of gestation, and perinatal mortality in rural western China: doubleblind cluster randomized controlled trial. BMJ 2008; (337): 1-10.

13. Hininger I, Favier M, Arnaud J, et al. Effects of a combined micronutrient supplementation on maternal biological status and newborn anthropometrics measurements: a randomized double-blind, placebo-controlled trial in apparently healthy pregnant women. Eur J Clin Nutr 2004; 58: 52-9.

14. Scholl TO, Hediger ML, Bendich A, Schall JI, Smith WK, Krueger PM. Use of multivitamin/mineral prenatal supplements: influence on the outcome of pregnancy. Am J Epidemiol 1997; 146: 134-41.

15. Shah PS, Ohlsson A; Knowledge Synthesis Group on Determinants of Low BirthWeight and Preterm Births. Effects of prenatal multi-micronutrient supplementation on pregnancy outcomes: a meta-analysis. CMAJ 2009; 180:1200-6.

16. UNICEF. Preventing and controlling micronutrient deficiencies in populations affected by an emergency. WHO. 2007.

17. WHO. FAO. Guidelines on food fortification with micronutrients. Editor Allen L, Benois B, Dary O, Hurrel L. 2006.

18. Caufield LE, Zavaleta N, Shankur AH. Merialdi M. Potential contribution of maternal zinc supplementation during pregnancy to maternal and child survival. AJCN 1998; 65:499508.

19. Kurniawan A. Policies in alleviating micronutrient deficiencies: Indonesia's experience. Asia Pacific J Clin Nutr. 2002; 11(3):360-70.

20. Indonesia Health Profile 2007. Department of Health Republic of Indonesia 2008. 